\title{
Introduction: Gaining insights into English as a contact language and its diffusion
}

\author{
Ignacio M. Palacios Martínez \\ Universidade de Santiago de Compostela \\ ignacio.palacios@usc.es \\ José A. Sánchez Fajardo \\ Universidad de Alicante \\ jasanchez@ua.es
}

The aims of this volume are twofold: to contribute to the study of English as a contact language and its various manifestations in World Englishes, and to explore the causes and effects of the influence and diffusion of English in several languages, with particular reference to Spanish.

As Schreier and Hundt (2013: 1) have noted, the English language "has been contact derived from its very beginnings" and to this we can add that due to its rapid and far-reaching extension, leading to its current role as a global contact language (Görlach, 2002), it continues to be closely connected to a wide range of communities of speakers and languages across the world. In fact, as Onysko (2016: 192) claims, "the notion of language contact emerges as a valid candidate for being a unifying characteristic of all Englishes".

The effects of this language contact can sometimes be seen in the influence of the substrate(s) language on new varieties of English, bringing about changes and innovations in the system. However, not all changes and innovations can be attributed exclusively to the role of the substrate element, since cognitive and transfer processes may also play a part here. Furthermore, sociolinguistic factors such as language attitudes and group identity might also be in operation. In broad terms, the outcomes of language contact can be seen in a number of contact-induced phenomena, including borrowing, phonological change, language transfer, relexification, code mixing, creole formation and code-switching, among others (Sankoff, 2001; Winford, 2005).

The contributions in this volume will thus address the following issues of English as a contact language and its diffusion: syntactic complexity and language contact in traditional and New Englishes, English as a lingua franca in ESP contexts, contactinduced variation in clausal verb complementation in World Englishes, factors determining the degree of rhoticity in Expanding Circle Englishes, language contact in Gibraltar English, the influence of English in Arabic word-formation, the presence of English on internet forums and in the description of fashion and cosmetic products 
addressed to speakers of Spanish, the dynamics of English/Spanish code-switching and anglicisms in twenty-first century Spanish press.

In the light of this, we have organised the chapters into two main sections. The first will deal with theoretical and empirical issues in the study of English contact in World Englishes, and the second will reflect new trends and methodologies in the understanding of anglicized lexis, looking at particular genres and different languages where the presence of English is clearly observed.

\section{Theoretical and empirical contributions to the study of English contact in World Englishes}

A detailed account of the state of the art regarding the nature and evolution of World Englishes is beyond the scope of this introduction. (See, to mention just a few, Kirkpatrick, 2007; Kachru et al., 2009; Melchers and Shaw, 2011; Schneider, 2011, 2013; Buschfeld et al., 2014; Schreier, 2014; Seoane and Suárez-Gómez, 2016). Here we will simply mention some of the main issues as a means of introducing, contextualizing and better understanding the studies included in this section.

First of all, a note on terminology. We have already used several terms, World Englishes, New Englishes, Expanding Circle Englishes, to refer to what is essentially the same concept: those varieties of English that have emerged in different parts of the world, more particularly in Africa and Asia, and which in many cases have become national languages with their own status in the administration, political and educational domains of the respective countries. Other terms used on the same lines include Postcolonial Englishes, Extraterritorial Englishes, Indigenized Englishes, NIVES (NonNative Institutionalized Varieties of English) and Nativized Varieties. These do not always have precisely the same meaning, with some carrying specific nuances, although on the whole they share the same core sense (See Schenider, 2013: 132-133, for a discussion of this issue). In this volume we will generally use World Englishes, in that it is considered to be one of the most neutral terms.

The field of World Englishes is now a well-established one, to the extent that several international journals exist (English World Wide, World Englishes-Journal of English as an International and Intranational Language), as well as a number of handbooks and collected volumes (see above for some of these), an academic organization, the International Association for World Englishes (IAWE), conferences, and a very considerable amount of internationally published scholarly work on different issues in the field.

Corpus linguistics has played a central role in the study of World Englishes and, in this respect, the ICE project (International Corpus of English) including twenty-six components on specific varieties (Canada, East Africa, Hong Kong, India, Ireland, Jamaica, New Zealand, the Philippines, etc.) has made it possible to conduct comparative studies, since all components share the same size, one million words, and the compilation follows a similar format in terms of corpus design and grammatical annotation. Indeed, several subcorpora of ICE have been used by contributors in this 
volume, such as Tamaredo-Meira and Loureiro-Porto \& Suárez-Gómez, and these latter authors are themselves presently compiling the ICE component on the variety of English spoken in Gibraltar.

Another of our contributors, P. Romasanta, uses the Corpus of Global Web-based English (GloWbe), created by Mark Davies and released in 2013. Containing some 1.9 billion words of blog texts from twenty different countries, it is a very useful tool for research, not least because of its size. The international organization of Corpus Linguistics ICAME (International Computer Archive of Modern and Medieval English) ${ }^{1}$ also offers several corpora of this kind, such as the Australian Corpus of English (ACE), the Wellington Corpus of Written and Spoken English (New Zealand) and the Kolhapur Corpus of Indian English. To this list we can add a number of diachronic corpora, such as ARCHER (A Representative Corpus of Historical English Registers), the Corpus of Early New Zealand English (CENZE), the Corpus of Early Nineteenth-Century Ontario Newspaper English, the multigeneric Strathy Corpus of Canadian English, the Old Bailey Corpus, and the Historical Corpus of Singapore English, to mention just a few. (See Collins, 2015 for further information on all these corpora, plus findings from grammar studies that use them).

In addition to this, the Electronic Atlas of the Varieties of English (eWAWE 2.0, November 2013), designed and compiled at the University of Freiburg, Germany, by Kortmann and Lunkenheimer, is an extremely useful tool for research in this area, since it provides information on 235 morphosyntatic features in a total of 76 varieties of English, including traditional dialects, high-contact mother-tongue Englishes, indigenized second-language Englishes and English-based Pidgins and Creoles. ${ }^{2}$

We should also make brief reference to the main models that have been proposed to explain the development of World Englishes and to classify all these varieties (See Kirpatrick, 2007: 30-35, for more detailed information). Kachru's (1985) 'Three Circles' model is perhaps regarded as being the most traditional. This model establishes British English and American English within the first circle, Philippines English, SouthAfrican English and Indian English, for example, are classified in the second circle, whereas varieties of English associated with China, Russia or Korean would be included in the Expanding Circle. It has been quite controversial in that it is static and thus cannot easily account for the dynamism of many World Englishes, where the role and status of varieties may change in a relative short space of time. Secondly, as Kirpartrick claims (2007: 29-30), the model "underestimated the roles that English would come to play in Expanding Circle countries". A more comprehensive and more widely accepted approach is that of Schneider's (2003) dynamic model, in which five main phases or stages are identified: foundation, exonormative stabilisation, nativization, endonormative stabilization and differentiation. The first of these, foundation, refers to the phase in which English establishes itself in a country where this did not previously exist. Exonormative stabilization is said to be the stage in which the new variety follows the pattern introduced by the settlers. In the third phase, nativization, the two existing varieties come together and the English language is heavily restructured, particularly regarding vocabulary and grammar. This leads to the 
following stage, endonormative stabilization, in which the new variety is gradually accepted by the community. Finally, in the differentiation period the new variety is widely used, reflecting the local community and culture. More recently, Mair (2016) has applied de Swaan's systems-theoretical model of global multilingualism to World Englishes to set out a new proposal, one which draws our attention to recent aspects of globalization illustrated by the migrations produced following the Cold War, the influence of the entertainment industry, and the revolution in communications resulting from the rise of the Internet. In this model Standard American English is considered to be "the hub of the World System of Englishes" (2016: 24).

This brief consideration and contextualization of the field leads us on to the contributions in the current volume. The first study of this section, by Yolanda Joy Calvo Benzies, of the University of Balearic Islands (pages 27-60), deals with student attitudes towards non-native speech in ESP teaching materials. Her approach combines pedagogical and attitudinal perspectives on non-native accents in the context of a new use and variety of the English language, English as a Lingua Franca (ELF), which itself can be seen as a contact language, in that it is adopted by different groups of speakers with their own native languages who decide to make use of a common code for communicative purposes.

Yolanda Calvo's paper is in fact divided into two main parts. In the first, she looks at the presence of native and non-native accents in ESP textbooks through an analysis of the CD tracks from six ESP textbooks for students of Law, Business and Tourism. Her results show, as expected, that native speakers prevail $(70 \%)$ over non-natives ones, while less than $5 \%$ of the tracks contain only non-native speakers. On the whole, the combination of both native and non-native types of speakers seems to be the norm, and in broad terms non-native accents are quite well presented in these textbooks. From this, and bearing in mind the limitations of the sample considered, one might suppose that a change in the general approach to English language teaching is now gradually taking place, with teachers exposing their students to non-native accents and not limiting themselves to native speakers of English as the model to follow.

The second part of Calvo's study focusses on students' attitudes towards these nonnative varieties. For this purpose, two questionnaires, adopting a Likert scale from 1 to 10, were administered to a total of 14 Law and Tourism ESP students. Five specific non-native accents were selected, these being from native speakers of German, French, Chinese, Polish and Spanish. Results indicate that all subjects regard having good pronunciation of English very positively and they all maintain that it is not possible to have a good command of spoken English if one does not know how to pronounce words well.

As regards attitudes to non-native accents, Tourism students seem to be more flexible to such accents while Law students value native accents more markedly. Considering the specific non-native accents, speakers of English, German and Polish are the most highly rated by these students while French and Spanish speakers receive the most negative responses. All in all, this study draws our attention to the relevance of including audio materials of non-native speakers of English in general and ESP courses. 
The study also shows that the emergence of a new variety of English such as ELF may have a direct impact on the learning materials and, as a result, on the whole teaching process, particularly in regard to language activities and the standard to be used as a model.

The paper by Li and Kabak, of the Universities of Münster and Würzburg (Germany) respectively (pages 61-91), discusses the realization of postvocalic $/ \mathrm{r} / \mathrm{in}$ Chinese English, often seen as one of the most notable phonotactic differences in accents of English. However, while rhotic sounds have been widely researched in the Inner and Outer Circle varieties, this is not the case in Expanding Circle Englishes, such as Chinese English. This study, then, is a very useful contribution in this area.

The authors start by describing in detail the variant $/ \mathrm{r} /$ in Inner Circle, Outer Circle and Expanding Circle Englishes, before focussing on rhoticity in Mandarin Chinese as a means of understanding its influence in Chinese English. The following section presents the methodology used, which is based on the elicitation of data from a total of 13 teachers of English by means of 3 instruments: a reading aloud task (a short story), a free speech task in English on one or two topics from a list provided, and reading a text aloud in Mandarin Chinese. This was complemented by a questionnaire in which participants were asked to provide personal information about their learning of English and other languages, and their preferences and attitudes towards a particular standard (British English versus American English).

A total of 762 instances of the production of $/ \mathrm{r} /$ were elicited, and these were then coded according to several demographic and speaker-specific variables (age, language attitude, L1 Mandarin rhoticity, speech style, additional language(s) spoken, etc.) and linguistic factor groups (preceding vowel, stress and syllable structure).

The results show that Chinese English, as represented by these 13 teachers of English, is only slightly rhotic. Considerable variation across participants is found, with a proportion of rhoticity ranging between $40 \%$ to $60 \%$. A multivariate analysis of the data also reveals that the preceding vowel is the most significant influencing factor here, while stress and syllable structure were not significant. Moreover, those subjects with American English as target norm tended to produce rhoticity while this was not the case with those who opted for the British English standard. Speech style is also a determining factor, since Chinese English speakers produce more rhotic sounds in free speech than in the reading task. This, in the authors' views, could be related to the degree of formality of the two tasks. By contrast, rhoticity in the L1 does not seem to exert as significant an influence as expected.

The authors conclude by suggesting that in broad terms Chinese English is closer to the American English accent, and they relate their findings, in line with Mair's theory (see above), to the Dynamic System Theory (DST) approach to multilingualism and second language acquisition, in which languages are seen to be constantly evolving and developing. This leads them to formulate a new model for sound patterns, the 'Dynamic Equational Approach', in which sound patterns are characterized by a degree of gradience and variability as the result of the interplay of a number of language-internal and extralinguistic factors. 
The paper by Lucía Loureiro-Porto and Cristina Suárez-Gómez (pages 93-119), both senior lecturers of English at the University of Balearic Islands, deals with a variety of English that is very close to us, the English spoken in Gibraltar. As they explain, this variety of English is particularly interesting in that it has been in close contact for centuries not only with Spanish but also with Italian, Hebrew and Arabic.

The study is organised into two main parts. In the first of these, the authors describe the current state of the compilation of the Gibraltar component of the International Corpus of English (ICE) which they are compiling together with Elena Seoane, University of Vigo, and Jennifer Ballantine Perera, University of Gibraltar. This team was commissioned in 2014 to compile the ICE-GBR and thus far 100,000 words have been collected. It is also worth noting in this respect that the compilation of this corpus will fill an important gap in the literature and in World Englishes research in general, since there is currently no similar corpus that allows for the empirical study of this variety with hard, reliable and representative data.

In the second part of the study, several morphosyntactic features are analysed by looking at the extent to which contact with Spanish is indeed present and can be identified. For this purpose, they analyse the section on press new reports in the corpus, amounting to a total of 40,000 words, and compare it with a sample of a similar size and nature from the British English component of the ICE corpus (ICE-GB). Four main issues are examined: the frequency of the passive voice, relative markers, the use of titles ( $\mathrm{Mr}, \mathrm{Dr}, \mathrm{Sir})$ and pseudo-titles (Tory, therapist), and code-switching.

The results show that in the case of the passive voice the low frequency of this construction in Gibraltar English may be explained by contact with Spanish, in which it is not very common. Regarding relativizers, the authors hypothesize that the high frequency of the relative que in Spanish could favour the use of its counterpart in English that. The data analyzed reveal that this can be applied to those examples with inanimate antecedents but not to those with animate ones. However, the latter tendency has been identified quite extensively worldwide, and thus in this case contact with Spanish as an explanation should be taken with care. As regards the use of titles and pseudo-titles, it was assumed that due to the influence of Spanish a lower frequency of these items in ICE-GBR than in ICE-GB would be detected. However, the opposite is true and the data show a significantly higher proportion of members of this category in Gibraltar English. Finally, several examples of code-switching were recorded in the press material studied. In general these uses were used for expressive purposes and were restricted to a few nouns such as alcalde and constructions such as mano a mano. These cases of code-switching are regarded by the authors as the clearest examples of the influence of Spanish on the variety of English spoken in Gibraltar.

The paper by Raquel P. Romasanta, of the University of Vigo (pages 121-147), is concerned with clausal verbal complementation in World Englishes, taking the verb regret as a case in point. Language contact and the causes and effects of this language contact constitute the starting-point of the study, in that the author aims to explore the extent to which the preference for finite patterns over non-finite structures in World Englishes (British English, American English, Jamaican English, Hong Kong English 
and Nigerian English, in particular) is conditioned by transfer processes from the substrate languages or by cognitive mechanisms derived from the language contact situation itself.

The results, based on the analysis of 14,984 attestations of this verb recorded from the General and Blogs components of the GloWbE (Global Web-based English corpus), ${ }^{3}$ show that the six possible complementation patterns identified by FrameNet (a lexical database of English based on examples of how words are actually used) ${ }^{4}$ for the verb regret (NP, wh-clauses, to-infinitive, -ing, that and zero) are all present in the five varieties of English considered. The use of a prepositional phrase as a complement of regret, as in regret about, regret for, is also reported, a finding which is not mentioned in general reference grammars or on FrameNet. Moreover, while British English and American English show similar distributions regarding finite versus non-finite complementation patterns, this is not true for the non-native varieties, these differences being highly significant statistically. Jamaican English seems to be the closest in its distribution patterns to the native varieties, followed by Hong-Kong English and Nigerian English.

The data also reveal that while British English and American English show a clear preference for non-finite patterns, this is not the case for the non-native varieties. As regards the effects of language contact on this feature, the author concludes that the absence of non-finite patterns in Cantonese may be responsible for the low frequency of finite and non-finite constructions found in Hong-Kong English. Something similar can be said of Nigerian English, since none of the three languages spoken in this country (Hausa, Igbo and Yoruba), or even French, the most popular foreign language learnt in Nigerian schools, have gerund forms. The case of Jamaican English is slightly different since the number of non-finite forms here is quite high, although this variety finds itself in an advanced phase of evolution as compared to the other non-natives ones considered.

Together with the influence of the substrate, the role of cognitive processes is also detected, in the form of hyperclarity and isomorphism. Thus, several variables and factors can be said to exist in a state of interplay in the phenomenon of clause contact, with sociolinguistic and cognitive probably two of the most significant.

IvánTamaredo, research scholar at the University of Santiago de Compostela, focuses in his paper (pages 149-182) on the study of relative clauses in British English and Indian English from the perspective of syntactic complexity. For this, he makes use of a corpus-based methodology analysing data extracted from the British and Indian components of the International Corpus of English. British English here represents a native variety while Indian English corresponds to a L2 variety which emerged under contact conditions and with a high exonormative influence.

The author defines the concept and the metrics of syntactic complexity by referring to previous descriptions in the literature, then turns to the complexity of relative clauses in particular. It is widely acknowledged that relative clauses are difficult to process, since they involve a relation of dependency between a gap and an antecedent, to the 
extent that it is possible to speak of an 'Accessibility Hierarchy', which means that languages differ with respect to the way they relativize.

After a general description of relative clauses in the two varieties selected, Tamaredo presents the main results of the study, derived from the analysis of over one thousand instances in 40 written and spoken texts from each of the ICE components. A total of 7 variables are considered (variety, text type, degree of restrictiveness, relativizer, relativizer position, preposition placement and relative clause complexity) and the data obtained are analyzed by means of a series of hierarchical configural frequency operations which reveal that British English shows a preference for covert relativizers (that and zero) in restrictive relative clauses, with a difference between speech and writing observed: while the former favours that, the latter prefers zero. In contrast, in Indian English overt relativizers, that is, wh-pronouns, are the preferred option. The results here include two findings which are considered unexpected: the high proportion of zero relatives in written informal texts in the two varieties studied, and the abundance of that relatives in spoken formal texts in Indian English.

The paper concludes by claiming that differences found with respect to relative formation in British English and Indian English can be accounted for by differences in syntactic complexity: speakers of Indian English are more prone to produce simpler relative clauses than British English speakers and they also tend to shun complex relatives in prepositional complement and genitive positions. We can say, then, that their condition as L2/L3 speakers of English may also explain their preference for relative clauses, which may be easier to process and understand.

\section{Exploring trends and methodologies in the study of anglicized lexis}

The rise of English as a lingua franca has been associated with the influx of anglicized lexis and phrases. Whether a 'plagued' word stock (cf. Graddol, 2006), or just a result of over-lexicalization, these English-induced loanwords have come into existence mainly due to an ingrained sense of terminological 'gap-filling' (pen-drive, chat), unknown referents in the target language (cultural borrowing), or merely a sociolinguistic restriction (slangy or jargoned language). However, despite these reasons, it is true to say that the vast majority of languages (if not all those which are connected to a globalized market) have been influenced by English at some point.

The diffusion of English has been traditionally linked to empowering Anglophone territories, and to their political and economic influence on neighboring countries. The United Kingdom and the United States, since the peak of the Industrial Revolution in the $19^{\text {th }}$ century, have laid the groundwork for an ensuing standardization of technical and trade-related terms. As expected, technological advances and globalization have given way to an extensive importation of 'the foreign' and the assimilation of 'the anglicized native'. Also, the dissemination of pop culture and mass media have greatly contributed to an era that has been described as 'English-dominated'. No doubt, the enactment of English as a communicative means in academic programs such as CLIL (cf. Marsh, 2002; Coyle et al., 2010) has guaranteed its ever-increasing linguistic 
permeability, particularly in economic and political blocks such as the European Union (Görlach, 2002; Furiassi et al., 2012). With all this in mind, the impact of English on languages and cultures offers an unparalleled opportunity to study the variability of contact languages in more detail.

The processes of code-switching and linguistic borrowing in these languages in contact are a reflection of how the nativization of English terms and phrases might trigger universal categories and trends. This is precisely where anglicists have focused their attention: the description and contrast of morpho-semantic variations in the target language due to the influence of English structures and patterns. This involves the implementation of specific methodological and typological procedures in the collection and analysis of data.

One of the most notable attempts to explore the process of linguistic borrowing is the Loanword Typology Project (henceforth LWT) (cf. Haspelmath and Tadmor, 2009), based on contributors from 41 languages. This non-English-based cross-linguistic approach, reflected in other, related works (Wichmann and Wohlgemuth, 2008; Wohlgemuth, 2009), has sought to describe the historical circumstances and evolution of loanwords. To put it another way, based on a fixed list of 1,460 semantic items (not words), contributors were given the task of indicating the existence of loanwords in their own languages. These counterparts were extremely useful as a means of identifying the historical evolution of words, and a variability scope of borrowing was established: 0- no evidence of borrowing, 1-very little evidence for borrowing, 3perhaps borrowed, 4-probably borrowed, 5-clearly borrowed (Haspelmath and Tadmor, 2009: 13).

Thus, one of the breakthroughs of $L W T$ involves unraveling the question of wordclass dependency and lexical accommodation in the process of linguistic borrowing, by comparing the lexical systems of various recipient languages. The objective of this study is "to get a clearer idea of lexical borrowability by examining the loanwords in a reasonably representative and reasonably large set of languages (say, 30-40 languages), and by making inductive generalization over the data assembled in this way" (Haspelmath, 2008: 3). The onomasiological perspective of this novel methodology is reflected in the semantic arrangement of lexical items. By establishing an initial list of meanings (not words), comparable lexical samples could be gathered, which are processed in terms of semantic word class, typical context, and morpho-syntactic traits.

The definition of a loanword, however, reflects the typological restriction of the concept of linguistic borrowing: a loanword is defined "as a lexeme that has been transferred from one lect into another and it is used as a word (rather than as an affix, for example) in the recipient language" (Haspelmath and Tadmor, 2009: 13). Although this limitation guarantees a parallel quantitative study and a comprehensive visualization of language contact, it does not add structural and conceptual distinctions between the processes of calquing and loaning: "loanword (or lexical borrowing) is here defined as a word that at some point in the history of a language entered its lexicon as a result of borrowing (or transfer, or copying)" (Haspelmath, 2009: 36). 
The second notable procedure worth mentioning here is corpus-based, and is intended to explore the linguistic impact of a source language (English) on a recipient one, provided that all types of lexical borrowing are collected and processed. Notwithstanding their limited scope (only two languages are involved), dictionary and corpus-based studies provide a general examination of language contact, including direct (loanword) and indirect borrowing (calque):

Through corpus-based research it is possible to carry out qualitative studies and improve microstructural features of general dictionaries and dictionaries of anglicisms, i.e. obtain information about frequency, period of adoption, usage context and authentic examples. Corpus-driven methods facilitate quantitative studies and contribute to the improvement of the macrostructure of general dictionaries and dictionaries of anglicisms by detecting new candidate entries (Furiassi et al., 2012: 18).

Alternatively, the GLAD (Global Anglicism Database) Network ${ }^{5}$ is aimed at studying the influence of a common source language (English) on a number of recipient languages (Spanish, French, German, Danish, Chinese, etc.). Based on national corpora and a common typological strategy (Furiassi et al., 2012), GLAD seeks to set up a global database of English-induced lexical units, revealing how English has affected these languages at the lexical, morphological, syntactic and pragmatic levels. The results are intended to depict common grounds and dissimilarities in the Anglicization of lexis, particularly in terms of morpho-phonological and semantic variations. In spite of its lexicon-centered perspective, such multicultural corpora are useful tools in the examination of global trends and converging paradigms. In addition, a semasiological study of loanwords can shed more light on both the typology of intralinguistic wordformation mechanisms and the extrapolation of English patterns in the target language.

One of the most visible, and intriguing, results of this importation is perhaps the pseudo-Anglicization process. A pseudo-anglicism, also known as a 'false' loan, has traditionally been defined as "a word or an idiom that is recognizably English in its form (spelling, pronunciation, morphology, or at least one of three) but is accepted as an item in the vocabulary of the receptor language even though it does not exist or is used with a conspicuously different meaning in English" (Furiassi, 2010: 34). Other authors (Filipović, 1985; Onysko, 2007; Balteiro and Campos, 2012; Furiassi and Gottlieb, 2015) have also contributed to the study of these units from phonological, morphological and semantic perspectives, particularly in the examination of European languages.

The richness of false loans lies in their inner expression of lexical creativity and interlinguistic transmutation, i.e. the acquisition of source-language traits and their combination with target-language ones. Also, pseudo-anglicization is characterized by the unlikelihood of English speakers detecting the meaning of the existing words, which might itself constitute a useful and delimiting way of looking at the phenomenon from the point of view of the 'monoglot' Anglophone reader or listener (cf. Furiassi and Gottlieb, 2015): footing 'jogging' in Spanish, Handy 'mobile phone' in German, caddy 'type of trousers' in Polish, to name a few. 
Like anglicisms in general, the adoption of false loans is motivated by a number of factors: language economy, in which brevity is key to understanding the coinage of shortened forms (cf. Furiassi and Gottlieb, 2015), and the "taste for the exotic, the charm of a foreign language, and the glamorous quirk of being creative and playing with language are the core motivations for the birth of false Anglicisms" (Furiassi, 2010: 62-63). Thus, the complexity of loanwords depends on word choice, semantic cues and sociolect. In other words, referential or speaker-related motivations can lead to the formation of 'new' words in the target language, with some updated underlying pragmatic and semantic features.

As discussed above, Spanish and English have long been regarded as languages in ever-increasing contact. The reasons are once again associated with geographical location, economic influence and immigration. In the nineteenth century, as Britain emerged as a world power, English began to exert a great influence on Spanish as it did on other European languages, and this influence increased greatly leading to the replacement of French as the main source of foreign loans in Spanish (cf. Rodríguez, 2002: 128). But it was not until the twentieth century that Spanish underwent a major Anglicization of its lexis, particularly due to the influence of an empowered United States, which wielded its considerable emerging economic and political influence over its neighboring countries on the American continents.

Technology is one of the domains that has characterized this predominantly southbound influence. Its adoption was induced by the rapid importation of referents and concepts. The ephemerality and haste in adopting this technolect by Spanish speakers has led to semantic extension and variation: bisnes ( $<$ business) is used colloquially for 'exchange of goods', but is also restricted to 'illegal business' in some Spanish-speaking South American countries. Such a transition denotes the semantic obscurity by which slang or jargon loanword stock is characterized, and the relation between pragmatic factors and diachronic shift.

The influence that English has had on Spanish is undeniable, reflected especially in the degree of 'cultural borrowing' (Weinreich, 1953; Gómez Capuz, 1998; Hoffer, 2002; Treffers-Daller, 2010). First defined as "loaned objects and practices that pass from one community to the other (cultural diffusion)" (Bloomfield, 1933: 444), a cultural loan is not another type of linguistic borrowing, but rather a transversal concept that depends on the features of the imported referent. The existence or not of referents or concepts in the target language determines the nature of a cultural loan. Halloween and laptop are unadapted anglicisms used in European Spanish, but they differ in the type of referent denoted: whereas Halloween is imported to convey a non-existent concept in Spanish, laptop coexists with portátil and is restricted to a specific technolect or jargon. The study of the pragmalinguistic dimensions or categories of cultural borrowing (cf. Sánchez, forthcoming 2018) is a reliable means of measuring the index of cultural density, that is, the impact that certain languages might have on their neighboring ones.

Simultaneously, a vast number of Spanish words or hispanicisms have been imported into English. Approximately a thousand of these loanwords have been attested 
in the Oxford English Dictionary (Rodríguez, 2001: 84), and this number is yet higher in American English, unlike in other English variants. Hispanic or Latino migration plays a fundamental role in this borrowing process, which is particularly tangible in bordering territories of North-America such as New Mexico, Florida and California. These territories abound in Spanish-origin toponyms: Los Angeles, San Francisco, Santa Barbara, etc., which have left an imprint of over two hundred years of Spanish dominance in the area.

The import of Spanish words, as above, is frequently conditioned by the lack of referents in English, particularly when referring to non-American cultural traits: sombrero'a Mexican hat', abogado 'lawyer specialized in immigration cases', taco, tamale (<tamal). The impact of the Hispanicization of English is also visible in the coinage of colloquial phrases, in which these Spanish or hybrid units are motivated by a sense of 'intentional disguise' (Galinsky, 1964) or marginalization: zero, nothing, nada; mi casa essu casa.

However, it is the emergence of Spanglish what has intrigued Spanish and English sociolinguists most, due to the creation of common lexical and syntactic patterns. Regardless of its acceptance or so-called intrusiveness, Spanglish has generally been recognized as "a pidgin, or creole language; an interlanguage; or an Anglicized Spanish language" (Neuliep, 2015: 105). The nature of Spanglish does not rely to any great extent on the intricate and diverse forms of code-switching and lexical borrowing, but on the communicative and pragmatic functions conveyed by what has been called "a dynamic fusion of crashing cultures noticeably merging at the interface of language" (Rothman and Rell, 2005: 516). Following Jakobson's functional framework, Appel and Muysken (cf. 2005) have associated the six language functions with the switching process:

(a) referential: the non-existence of concepts and items in the target language, or the sense of confidence of bilingual users when using certain words in specific communicative settings.

(b) directive: the exclusion or inclusion of hearers in a conversation.

(c) expressive: speech characterized by stretches of mixed language, in which two identities are easily recognized.

(d) phatic: changes in the tone of a conversation, these in accordance with the language used.

(e) metalinguistic: allusions to both languages directly or indirectly, depending on the message.

(f) poetic: the use of stylistic tropes in both languages, these intended to make use of bilingual puns, jokes, etc.

The study of the contact between Spanish and English is of great relevance due to the sociolinguistic and historical repercussions underlying the processes of codeswitching and borrowing. Two of its more practical contributions here are the examination of hispanicisms and anglicisms in both languages, and the analysis of how 
these imported units are restricted variably to certain lects. Spanglish is perhaps the most palpable interlinguistic (Spanish and English) construct that results from bilingualism and acculturation. Its functions and trends might shed more light on the understanding of analogous mixtures such as "Taglish (Tagalog-English in the Philippines), Hinglish (Hindi-English in India), Franglais (mixture of French and English), Portuñol/ Portunhol (Portuguese-Spanish), Guarañol (Guaraní-Spanish), and many others" (Lipski, 2008:40).

Given the comprehensive dimension of the contact of English and other languages, this volume on 'World Englishes' and the diffusion of English, as discussed above, intends to go beyond the examination of existing varieties of English, and to present readers with some analysis of the Anglicization of languages, in particular Spanish. As such, this section (Part II) of the special issue of Revista Alicantina de Estudios Ingleses (RAEI) presents studies on the influence of English on dissimilar languages such as Spanish, Arabic and Russian. These articles contribute to a better understanding of specific linguistic cases and their methodological principles, towards an understanding of what type of converging foreign trends are imported, and more importantly, how these structures and patterns are adapted in the target or recipient language. Much attention has been devoted here to Spanish, with four studies that show how these variations occur in different semantic fields, such as fashion or the media, and how the process of establishing a database could itself be driven by the features of the wordstock in question.

With theoretical issues in mind, this part of the volume opens with the paper "English lexical items in Egyptian Arabic. Code-switching or borrowing?" (pages 185210), in which Malgorzata Kniaź, of the Jagiellonian University, explores the conceptual differences of code-switches and borrowings in an analysis of 3,443 bilingual projections of complementizers. The use of the Matrix Language Model reveals how disparities in the results are a reflection of the situation of English in the Arab world. The article includes an in-depth study on the phenomena of code-switching and borrowing, which are seen explicitly as a continuum, as suggested by previous work in the field (cf. Toribio, 2015).

An outstanding aspect of this article is the correlation between the structural characteristics of languages in contact and the sociolinguistic contexts of speakers. More specifically, in this case study it is found that those speakers lacking knowledge of Standard Arabic are more prone to fill lexical gaps through the acquisition of English loanwords, and the shortage of morphological integration is driven by the visible incongruence of these two languages, as opposed to other Indo-European ones, such as French, German, Spanish, etc.

Following this, Elizaveta Tarasova, of the Institute of the Pacific United in New Zealand, focuses on the assimilation of morphological patterns from English into Russian, particularly denominal compound nouns. Based on Krysin's principle (1975), the author asks whether these loanwords are still productive and how instances of English morphology might be duplicated. Interestingly, Tarasova introduces her study by providing non-Russian speakers with a thorough explanation of how $\mathrm{N}+\mathrm{N}$ 
compounding occurs in Russian morphology, which clarifies some analogous wordformation mechanisms in the two languages.

In terms of morphology, the author makes a comprehensive analysis of the nature of compound bases and their derivational paradigms in the target language. The Russification of imported units is also examined as a mechanism of semantic variation, in that some of the resulting constructs seem to be "stylistically coloured and belong to expressive vocabulary" (pages 211-236). Her study not only seeks to confirm whether $\mathrm{N}+\mathrm{N}$ is still a productive pattern in Russian, but also provides readers with a valuable analytical procedure that might be used for the analysis of other borrowed composites.

As suggested above, this volume is especially aimed at presenting current research on the Anglicization of Spanish lexis. To have a better understanding of how different analytical procedures can lead to the examination of same-domain loanwords, two articles on fashion and beauty have been included: "Present-day Spanish Fashion Lexicon Dresses up in English", by Beatriz Rodríguez Arrizabalaga", of the University of Huelva (Spain), and "Analysis of the Presence of Anglicisms in an Internet Forum: Some Terms of the Fields of Fashion, Beauty, and Leisure", by Carmen Luján García, of the University of Las Palmas de Gran Canarias (Spain).

In the examination of Rodríguez's findings (pages 239-276), readers are given a valuable analysis of the impact of English on the media and advertising. This is a necessary step in understanding the motivations underlying the diffusion of an anglicized lexicon in the Spanish fashion industry. Although the paper centers on a corpus-based analysis of 14 anglicized lemmas related to the domain of 'fashion', its relevance lies in the study of these 'superfluous' loanwords (cf. Pratt, 1980; Lorenzo, 1996) and their autochthonous Spanish equivalents. The resulting quantitative data shows a diachronic progression of lexical frequency and word variation, illustrating the ever-increasing dominance of gratuitous anglicisms in the fields of marketing and sales.

Similarly, Luján's paper (pages 277-300) looks at the semantic fields of 'fashion', 'beauty' and 'leisure' through the analysis of corpus-based data. The study is divided into three overall stages: (i) extraction of English-induced lemmas, (ii) classification of anglicisms (Furiassi and Gottlieb, 2015), and (iii) exploration of their morpho-syntactic peculiarities. The final stage provides valuable reflections on the semantic change undergone by some of the lemmas that have been classed as 'pseudo loan', and the type of orthographical and phonological variations that might be involved. The use of quantitative data and authentic contexts are of great value here in supporting some of the findings with regard to borrowing typology and frequency.

Following these studies on fashion-related loanwords from diachronic and synchronic perspectives, Cristina Tejedor Martínez, of the University of Alcalá (Spain), also uses a corpus-based procedure to describe the process of Anglicization in the domain of cosmetics. Her paper, "Mixing English and Borrowings in the Description of Cosmetics Products" (pages 303-329), is based on the compilation of English-induced loanwords, previously retrieved from authentic texts used in the advertising campaigns of well-known cosmetic brands in Spain. The resulting corpus is examined and contrasted by using well-known prescriptive dictionaries of both English and Spanish, 
which allows for a clear-cut distinction of anglicisms and pseudo loans. One early quantitative finding indicates that cosmetology loans are not as frequent as other productive domains in Spanish, such as computing and tourism, although a significant number of them are indeed found. A morphological exploration reveals a duplicity of English word-formation patterns, which is complemented by some comments on the psychological impact of these words on consumers.

The corpus-based studies in this section, though apparently similar in the scope of the research, are effective in the analysis of anglicized lexis from various perspectives: semantic equivalency, morpho-syntactic variation, dia-synchronic evolution, etc. Not only do their findings add clarity to our understanding of linguistic borrowing in Spanish, but they also complement a multilinguistic examination of the target language with brief pragmatic commentaries on speakers' intentions and the nature of referents.

As noted above, the presence of Spanish-induced words in English is also a result of the process of language contact, although it has traditionally been related to historical and social phenomena, such as Spanish settlements in North America and migration. $\mathrm{M}^{\mathrm{a}}$ Isabel González Cruz, of the University of Las Palmas de Gran Canarias (Spain), discusses the presence and diffusion of Hispanicisms in two samples of romances, as part of a more ambitious project devoted to the compilation of a corpus of these lexical borrowings.

The examination of 16 romances is aimed at exploring the socio-pragmatic cues and discourse functions that characterize the processes of code-switching and lexical borrowing. By studying the implicatures of borrowing in literary texts, the author examines the predominant type of code-switching according to Lipski's classification model (1982). González Cruz's study, "Exploring the dynamics of English/Spanish code-switching in a written corpus" (pages 331-355), uses literary sources because they afford a clear perspective on the variability of code-switches in the target language. In doing so, the study contributes to a practical exploration of how these underlying motivations are associated with the degree of borrowability and the typology of the units collected.

Language contact and the diffusion of English are necessarily intertwined. The anglicizing impact of this lingua franca results in multifaceted variation in the target languages, and in a pragmatic and semantic transmutation of native units. As such, it represents a complex area of research. Exploring analytical procedures and analogous word-formation patterns contributes to a greater understanding of both the gradable influence of languages in contact and the pragmatic values of anglicized lexis and syntax in a globalized world. We commend all the authors in this volume for their valuable contributions to the field.

\section{Notes}

1. See: $<$ http://clu.uni.no/icame/>

2. See: $<$ http://ewave-atlas.org//>for further information.

3. See: $<$ https://corpus.byu.edu/glowbe/ $>$. 
4. $<$ https://framenet.icsi.berkeley.edu/fndrupal/>

5. $<$ https://www.nhh.no/en/research-centres/global-anglicism-database-network/>

\section{References}

Appel, Rene and Pieter Muysken (2005): Language Contact and Bilingualism. Amsterdam: Amsterdam University Press.

Balteiro, Isabel and Miguel A. Campos (2012): "False anglicisms in the Spanish language of fashion and beauty". Ibérica, 24: 233-260.

Bloomfield, Leonard (1933): Language. New York: Holt, Rinehart and Winston.

Buchsfeld, Sarah, Thomas Hoffmann, Magnus Huber \& Alexander Kautzsch, eds., (2014): The Evolution of Englishes: The Dynamic Model and Beyond [Varieties of English around the World G49]. Amsterdam \& Philadelphia: John Benjamins.

Collins, Peter, ed. (2015): Grammatical Change in English World-Wide. Amsterdam \& Philadelphia: John Benjamins.

Coyle, Do, Phillip Hood and David Marsh (2010): CLIL. Cambridge: Cambridge University Press.

Furiassi, Cristiano (2010): False anglicisms in Italian. Milano: Polimetrica.

Furiassi, Cristiano, Virginia Pulcini and Félix Rodríguez (2012): The Anglicization of European Lexis. Amsterdam \& Philadelphia: John Benjamins.

Furiassi, Cristiano and Henrik Gottlieb, eds. (2015): Pseudo-English. Studies on False Anglicisms in Europe. Berlin: De Gruyter Mouton.

Galinsky, Hans (1964): "Stylistic aspects of linguistic borrowing. A stylistic and comparative view of American elements in Modern German and British English". In H. G. Lunt, ed., Proceedings of the 9th International Congress of Linguistics. Cambridge, Mass., August 2731, 1962. The Hague: Mouton, 374-381.

Gómez Capuz, Juan (1998): El préstamo lingüístico. Conceptos, problemas y métodos. Valencia: Universidad de Valencia.

Görlach, Manfred (2002): English in Europe. Oxford: Oxford University Press.

Graddol, David (2006): English Next: Why Global English May Mean 'the End of English as a Foreign Language'. London: British Council.

Filipović, Rudolf (1985): "Pseudoanglicisms in European languages". In U. Pieper and G. Stickel, eds., Studia Linguistica Diachronica et Synchronica. Werner Winter Sexagenario. New York \& Berlin: De Gruyter, 249-255.

Haspelmath, Martin (2008): "Loanword typology: Steps toward a systematic cross-linguistic study of lexical borrowability". In T. Stolz, D. Bakker and R. Salas Palomo, eds., Aspects of Language Contact: New Theoretical, Methodological and Empirical Findings with Special Focus on Romancisation Processes. Berlin: Mouton de Gruyter, 43-62.

Haspelmath, Martin (2009): "Lexical borrowing: concepts and issues". In M. Haspelmath and Uri Tadmor, eds., Loanwords in the World's Languages: A Comparative Handbook, 35-54. Berlin: De Gruyter Mouton.

Haspelmath, Martin and Uri Tadmor (2009): "The loanword typology project and the world loanword database". In M. Haspelmath and U. Tadmor, eds., Loanwords in the World's Languages: A Comparative Handbook. Berlin: De Gruyter Mouton, 1-34.

Hoffer, Bates L. (2002): "Language borrowing and language diffusion: An overview". 
Intercultural Communication Studies, 11(4): 1-37.

Kachru, Braj B. 1985: "Standards, codification and sociolinguistic realism: The English language in the Outer Circle". In R. Quirk and H. Widdowson, eds. English in the World. Cambridge: Cambridge University Press, 11-30.

Kachru, Braj B., Yamuna Kachru and Cecil L. Nelson, eds. (2009): The Handbook of World Englishes. Oxford: Blackwell.

Kirkpatrick, Andy (2007): World Englishes: Implications for International Communication and English Language Teaching. Cambridge: Cambridge University Press.

Krysin, Leonid (1975): "Stupeni morfemnoi chlenimosti inoyazychnyh slov". In E. Zemskaya, ed. Razvitie sovremennogo russkogo yazyka. Slovoobrazovanie. Chlenimost' slova. Moscow: Prosveshchenie, 227-231.

Lipski, John M. (1982): "Spanish English language switching in speech and literature - theories and models". The Bilingual Review, 9(3): 191-212.

Lipski, John M. (2008): Varieties of Spanish in the United States. Washington, D.C.: Georgetown University Press.

Lorenzo, Emilio (1996): Anglicismos Hispánicos. Madrid: Gredos.

Mair, Christian (2016): "Beyond and between the "Three Circles": World English research in the age of globalisation". In E. Seoane and C. Suárez. World Englishes. New Theoretical and Methodological Considerations. Amsterdam \& Philadelphia: John Benjamins, 17-35.

Marsh, David, ed. (2002): CLIL/EMILE- The European Dimension: Actions, Trends and Foresight Potential. Brussels: European Commission.

Melchers, Gunnel and Philip Shaw (2011): World Englishes [The English Language Series]. London: Hodder Education.

Neuliep, James W. (2015): Intercultural Communication. A Contextual Approach. Thousand Oaks: Sage Publications.

Onysko, Alexander (2007): Anglicisms in German: Borrowing, Lexical Productivity and Written Codeswitching. Berlin \& New York: De Gruyter.

Onysko, Alexander (2016): "Language contact and world Englishes". World Englishes. Language Contact and World Englishes. Special Issue 35(2): 191-195.

Pratt, Chris (1980): El Anglicismo en el español peninsular contemporáneo. Madrid: Gredos.

Rodríguez González, Félix (2001): "Spanish contribution to American English word-stock: An overview". Atlantis, 23(2): 83-90.

Rodríguez González, Félix (2002): "Spanish". In M. Görlach, ed. English in Europe. Oxford: Oxford University Press, 128-150.

Rothman, Jason and Amy B. Rell (2005): "A linguistic analysis of Spanglish. Relating language to identity". Linguistics and Human Sciences, 1(3): 515-536.

Sánchez Fajardo, José A. (Forthcoming 2018): "The pragmalinguistic dimensions of cultural borrowing". International Journal of Language and Culture. Amsterdam \& Philadelphia: John Benjamins.

Sankoff, Gilliam (2001). "Linguistic outcomes of language contact". In P. Trudgill, J. Chambers and N. Schilling-Estes, eds., Handbook of Sociolinguistics. Oxford: Basil Blackwell, 638-688.

Schneider, Edgar. W. (2003): "The dynamics of New Englishes: From identity construction to dialect rebirth". Language, 79(2): 233-281.

Schneider, Edgar W. (2011): English Around the World: An Introduction. Cambridge: Cambridge University Press.

Schneider, Edgar W. (2013): "English as a contact language". In D. Schreier and M. Hundt, 
eds. English as a Contact Language. Cambridge: Cambridge University Press, 131-148.

Schreier, Daniel (2014): Variation and Change in English: An Introduction. Berlin: Eric Schmidt.

Schreier, Daniel and Marianne Hundt, eds. (2013): English as a Contact Language. Cambridge: Cambridge University Press.

Seoane, Elena and Cristina Suárez-Gómez, eds. (2016): World Englishes. New Theoretical and Methodological Considerations. Amsterdam \& Philadelphia: John Benjamins.

Toribio, Almeida J. (2015): “Code-switching among US latinos”. In M. Díaz-Campos, ed. The Handbook of Hispanic Sociolinguistics. Malden (Mass.): Wiley Blackwell, 530-552.

Treffers-Daller, Jeanine (2010): "Borrowing". In M. Fried, J.O. Östman and J. Verschueren, eds. Handbook of Pragmatics. Amsterdam \& Philadelphia: John Benjamins, 17-35.

Weinreich, Uriel (1953): Languages in Contact. The Hague: Mouton.

Wichmann, Søren and Jan Wohlgemuth (2008): "Loan verbs in a typological perspective". In T. Stolz, D. Bakker and R. Salas Palomo, eds., Aspects of Language Contact. New Theoretical, Methodological and Empirical Findings with Special Focus on Romancisation Processes. Berlin \& New York: Mouton de Gruyter, 89-121.

Winford, Donald (2005): "Contact-induced changes: classification and processes". Diachronica, 22: 373-427.

Wohlgemuth, Jan (2009): A Typology of Verbal Borrowings. Berlin \& New York: Mouton de Gruyter. 